\title{
TELESNOSŤ AKO EXCENTRICKÁ POZICIONALITA V ANTROPOLÓGII A FILOZOFII BIOLÓGIE HELMUTHA PLESSNERA
}

JAROSLAVA VYDROVÁ, Trnavská univerzita v Trnave, Filozofická fakulta, Katedra filozofie, Trnava, SR

VYDROVÁ, J: Corporeality as the Excentric Positionality in Helmuth Plessner's Anthropology and Philosophy of Biology

FILOZOFIA, 76, 2021, No 7, pp. $487-498$

\begin{abstract}
The aim of the text is to analyse the impact of the project of philosophical anthropology elaborated by Helmuth Plessner, which will be demonstrated on the concept of corporeality seen in the framework of excentric positionality. In the first part of the text, we analyse the interference of philosophical anthropology and phenomenology (on the examples of lived body and oikos). This is based on historical as well as on deeper philosophical reasons. In this connection, we also find some practical applications of Plessner's project, e.g., in cultural anthropology, ethnology and pedagogy. In the second part, the problematics of "corporeality as excentric positionality" will be seen in the light of philosophy of biology and we open a dialog with a French biophysician Henri Atlan who focuses on characterisations of human, non-human and inhuman. Here, excentric positionality converges with emergence (autopoiesis) and corporeality becomes one of the sings of anthropological difference.
\end{abstract}

Keywords: Excentric positionality - Lived body - Physical body - Human - Nonhuman - Philosophical anthropology - Philosophy of biology

To, ako sa človek nachádza vo svete, vymedzuje jeden zo zakladatel'ov filozofickej antropológie Helmuth Plessner dynamickým určením takzvanej excentrickej pozicionality. Na rozdiel od centrickej pozicionality, v rámci ktorej sa nachádza organizmus v prostredí na spôsob centra, $v$ excentrickej pozicionalite sa človek voči centru vymedzuje, vzt’ahuje sa k nemu a uvedomuje si túto svoju situáciu ako určitý rozpor, ako nemožnost' založit' svoj život z centra. Perspektíva človeka sa zároveň neustále obmieňa, podlieha konfiguráciám podl'a situácií, $v$ ktorých sa ocitá - vo svete, v spoločnosti, dejinách. Toto „byt’ v situácii a zároveň vo vzt’ahu k nej“ predstavuje okolnost', ktorá neumožňuje stanovit' jeden stabilný základ či jadro l'udskosti. Preto sa pri pokuse vymedzit' povahu človeka stretávame u Plessnera skôr s pojmami ako 
nepreniknutel'nost' či nezaložitel'nost' (Unergründlichkeit) ${ }^{1}$, skrytost' (homo absconditus) a otvorenost': človek ako „otvorený sebe a svetu vie o vlastnej skrytosti““ (Plessner 2017, 357, 359). Tieto na prvý pohl'ad neurčité charakteristiky Plessner rozmieňa na drobné v detailných analýzach toho, ako sa človek nachádza vo svete a prejavuje sa vo výraze, ako svoju skúsenost' realizuje a prežíva v podvojnosti, vo vzt'ahoch a v ustanovovaní kultúrneho sveta. V záverečnej časti svojho t’ažiskového diela Stupne organického a človek (Plessner 1975) Plessner zachytáva toto „hl'adisko človeka“ v podobe troch antropologických zákonov umelej prirodzenosti, bezprostrednej sprostredkovanosti a utopického stanoviska. Inými slovami, tieto princípy vyjadrujú to, že človek ako excentrická pozicionalita sa stáva sám sebou vo výkonoch svojho života. V nasledujúcom texte sa dotkneme týchto jednotlivých výkladových rovín, ked’že v nich nadobúda konkrétnejšiu podobu to, čo Plessner označuje pojmom pozicionalita. $^{2}$

Jedným zo základných prejavov života, na ktorom sa dá charakterizovat' antropologická diferencia, teda to, akým spôsobom sa človek odlišuje od rastlinnej a animálnej sféry, ako sa nachádza de-centrovane alebo ex-centrovane, je telesnost. ${ }^{3}$ Plessner to vyjadruje napríklad takto: „,Ja som, ale seba nemám, ' to charakterizuje situáciu človeka v jeho telesnom bytí“ $(2017 b, 190)$. Práve optikou telesnosti sa pokúsime odpovedat' aj na to, prečo sa dnes vracat' k Helmuthovi Plessnerovi, ale aj to, kam treba čítanie Plessnerových textov situovat'. Bude to jednak v dialógu s fenomenologickou filozofiou, ktorá sa téme telesnosti a skúsenosti z prvej osoby venovala podrobne a s ktorou Plessnera spájajú dejinnofilozofické aj tematické východiská. A bude to v súvislosti s filozofiou biológie, ktorú pri skúmaní antropologickej diferencie Plessner ako zoológ zásadným spôsobom zohl’adňoval a rozvíjal.

Budeme teda sledovat': (1) prieniky aj reaktualizácie filozofickej antropológie v súvislosti s fenomenológiou (živá telesnost', telo a oikos); (2) možnost' rekonceptualizovat' pojem l'udského vo svetle filozofie biológie v dialógu s prístupom biofyzika Henriho Atlana, ktorý považuje práve telesnost' za znak l’udského rodu, ked’ uvádza: „L'udskost' druhu, to znamená všetkých, sa koncentruje v tele každého, v tejto fyziologickej realite a jeho vzhl'ade, ktorým sa vyjadruje aj realita jeho spoločenskej existencie“ (Atlan 2008, 115). V prvom prípade excentricita umožňuje sledovat'

\footnotetext{
${ }^{1}$ Spomeňme aj anglické výrazy, ktoré sa v súvislosti s prekladom tohto pojmu objavujú: indeterminacy, inscrutability, unfathomability.

${ }^{2}$ Uved'me v selektívnom výbere niekol'ko textov, ktoré môžu byt' vodidlom pri sledovaní týchto otázok: Význam mimického výrazu (Plessner 2016), O vzt'ahu sveta a okolia človeka (Plessner 2017a), Filozofická antropológa (Plessner 1970) a i.

${ }^{3}$ J. Halák a J. Klouda (2018) svoju výskumnú tému postavili podobným spôsobom: spoločný základ antropologickej diferencie v súvislosti s telesnost'ou hl'adajú v kontexte diela A. Gehlena a M. Merleau-Pontyho.
} 
konfiguráciu telesnosti $\mathrm{v}$ tom, že telom sme aj telo máme. $\mathrm{V}$ druhom prípade sa zase pozicionalita stáva vhodným pojmom pre procesy emergencie či autopoiésis.

\section{Telo ako vodidlo - prelínanie antropológie a fenomenológie}

Hlavnou témou Plessnerovej knihy, pomenovanej zhrňujúcim názvom Filozofická antropológia (kniha vo vydaní z roku 1970 obsahuje tri texty Smiech a plač, Úsmev, Antropológia zmyslov), je výrazová stránka l’udskej existencie, ktorá umožňuje zachytit' telesnost' $v$ jej špecifickej konfigurácii, $v$ ktorej sa človek ocitá ako živé telo (Leib), ktorým človek je a ktoré má ako fyzické telo (Körper) - ako určitý monopol a zároveň ako otázku excentrickej pozicionality. Plessner si volí špecifické skúsenosti - venuje sa plaču a smiechu ako takým rozporným situáciám, ktoré sa spájajú s narušením bežných očakávaných okolností, ${ }^{4}$ a ich osobitým prejavom, ktoré potom pôsobia ako duševno-telesné napätie a dezorganizácia vo vzt’ahu človeka $\mathrm{k}$ vlastnej telesnosti. Na jednej strane strácame kontrolu nad telesnými prejavmi, no na druhej strane sa uvolňuje vlastný výraz človeka ako plačúceho alebo smejúceho sa. Plessner tak poukazuje na fenomény, ktoré sú zároveň prirodzené, špecificky l'udské, no akoby pre ne chýbal primeraný spôsob pochopenia. Ten nenachádza v kauzálnej oblasti, ale v dynamike človeka ako telesnej, duševnej a duchovnej bytosti. Človek je tak bytost’ou, ktorej je vlastná možnost' čelit životným okolnostiam i podl'ahnút' nepochopitel'nosti a stratit' kontrolu nad situáciou. ${ }^{5}$

Plessnera zaujímajú modality a zákonitosti „sféry správania“, v ktorých sa prejavuje pozicionalita človeka v konkrétnom konaní alebo vo výrazoch (Plessner 2016, 89, 129; Plessner 2017b, 190 a n.). ${ }^{6}$ V činoch, gestách sa tak môžeme stretnút's fenoménmi telesnosti $\mathrm{v}$ hraničných či patologických prejavoch, ale prirodzene aj v bežných situáciách. Napríklad pohyb ruky môže mat'široké pole uplatnenia, od uchopovania po ukazovanie, ako gesto môže byt' vyslobodením zo situácie napätia, rozohraním úplne novej situácie, naopak, nemožnost' pochopit' alebo vyjadrit' gesto je pre človeka deficientná, až mu situácie de facto uzatvára. Prostredníctvom tela uskutočňujeme naše činnosti, pohybujeme sa, zároveň je telo prirodzenou hranicou, určuje dosah realizácie našej telesnosti, kam až dosiahneme, čo zvládneme. Telo je pôdou rezonancie, ktorá kulminuje v čine a výraze. Plessner to opisuje ako určitý druh

\footnotetext{
${ }^{4}$ Plessner opisuje rôzne aspekty tejto dynamiky: je tu prítomné určité napätie, zápas (Wettstreitphänomen) v súvislosti zmyslu a jeho narušenia, živelnosti a stereotypnosti napríklad pri komike (Plessner 2019, 177), ako aj odstup, uvol’nenie, ul'ahčenie, ktoré pôsobia na zvyčajné usporiadanie vzt'ahov, teda na ich ,zošnurovanú“" podobu $(183,189)$.

${ }^{5}$ Bližšie som sa tejto téme venovala v texte Pritomnost' človeka (Vydrová 2016).

${ }^{6}$ Text, na ktorý tu odkazujeme, pochádza z roku 1925 , ked' sa v Plessnerovej tvorbe začínajú naplno formovat' filozoficko-antropologické stanoviská. V predchádzajúcom období spolupracoval s Maxom Schelerom na svojej habilitácii a v roku 1928 vychádza jeho dielo Stupne organického a človek.
} 
naladenia, ktoré predstavuje aktuálnu súladnost' s prostredím - či už v podobe zladenia, alebo narušenia súladu. Pozicionalita tu potom predstavuje určité kvalitatívne rezonujúce echo našej telesnosti.

Ak pozicionalita znamená telesnú konfiguráciu organizmu v prostredí, tak v prípade človeka predstavuje rozvrhovanie vo svete, ako aj vzt’ah k sebe v pozíciách „tu“ a výmenou pozície „tam“, v pocit’ovaní vlastnej telesnosti, v konfrontovaní s vlastnými možnost’ami a hranicami, a to ako hranicami, ktoré zakúšame zvnútra i zvonka. Človek sa teda nachádza podvojne: skúsenostne je aktérom skúsenosti, no pritom zakúša vlastnú situáciu. Je telom, no má aj možnost' sa k svojmu telu vzt'ahovat' a o tejto svojej situácii vie. Dobrým príkladom toho, ako sa nás podvojnost' telesnosti ako Leibkörperlichkeit alebo Körperleiblichkeit dotýka, je tvorivá činnost' alebo proces učenia, ked' sa invencia alebo nové skúsenosti dosahujú v kombinácii so zvládnutými motorickými schopnost’ami. ${ }^{7}$ Dištancovanost', ktorá vzniká pri osvojovaní zručností a učení, nakoniec smeruje $\mathrm{k}$ jej prelomeniu v telesnom správaní: „Tento odstup vo mne a ku mne mi umožňuje ho prekonávat" (Plessner 2017b, 190). Inými slovami, človek je konfrontovaný sám so sebou, utvára sám seba tým, že sa k sebe vzt’ahuje (Plessner používa aj výraz Wechselverband).

Pozrime sa podrobnejšie na obe stránky tejto jednej mince ludskej telesnosti. Stránka Leib ako subjektívna telesnost', telesné bytie človeka nachádza východisko aj uplatnenie $\mathrm{v}$ početných fenomenologických analýzach tela, ktoré sa spolu s pohybom, zakúšaním pocit’uje. Funkčnú stránku subjektívnej telesnosti rozpracúva Husserl v Ideách II, ale aj v neskorších rukopisoch, ktoré sa orientujú na genetickú analýzu, intersubjektivitu, pasívnu syntézu či analýzu vnímania. Podrobné skúmanie a príklady nachádzame najmä v Merleau-Pontyho telesnej schéme. S telesnost’ou súvisí priame intencionálne zaangažovanie na konaní, správaní alebo rozvrhovaní situácie, ako aj pasívne vrstvy konštitúcie, neintencionálne zložky, ktoré sú však stále prejavmi subjektivity, nie kauzality (telo je unavené, nevládze, alebo je excitované, napäté a pod.). Ponúka sa tu teda prirodzene otázka prieniku medzi filozofickou antropológiou a fenomenológiou, ktoré sa prekrývajú alebo konvergujú. Môžeme k nej pristúpit' z oboch strán, čím vzniká tematicky i metodicky variabilný a hybridný prístup. ${ }^{8}$ Hlaadanie súvislostí medzi týmito dvoma paralelne sa vyvíjajúcimi smermi má svoj historický, no

\footnotetext{
${ }^{7}$ Ako príklad môžeme uviest' hru na nástoj, kreslenie či plávanie, ked' sa pri učení prelína fyzické telo so samostatnými výkonmi živej telesnosti, alebo naopak, ak sa nám daná činnost' nedarí, uvedomujeme si prevahu fyzického tela, narážajúceho na svoje hranice.

${ }^{8}$ Čo sa týka metodologických otázok, nemusia tu vznikat' konfúzie, ako o tom svedčí viacero analýz: porov. napr. (Zahavi 2019), (Wehrle 2013), (Vydrová 2021). Spomeňme zvlášt' aj prístup J. Brudzińskej: v štúdii nazvanej Fenomenológia ako antropológia skúsenosti a moderná filozofia človeka nachádza potenciál v skúmaní človeka v rámci fenomenológie ako teórie skúsenosti, fillozofie prirodzeného sveta, subjektívnej a intersubjektívnej antropológie, v zapojení perspektívy prvej a druhej osoby $(2018,20)$.
} 
aj vnútrofilozofický dôvod. Skúsenost' z prvej osoby, pohl'ad na subjektívnu telesnost' z nej samej, vyslobodenie z dualizmu a kauzálnych interpretácií umožňuje vidiet' „telo, a tým prirodzenost' človeka skôr ako súvislost' výkonu zmyslu (Sinnleistungszusammenhang)“" (Brudzińska 2018, 16). Zároveň antropológia s prienikom do oblasti kultúry si ako tému skúmania volí rôznorodé sféry l'udskej skúsenosti, čo sa naplno potvrdzuje v Plessnerovom diele, ktoré je bohaté na množstvo pohl'adov na oblasti l'udského prežívania a výrazu - v prípade telesnosti sú to napríklad emocionalita, šport, hra, socialita spojená s verejnými znakmi telesnosti (ako napríklad rola, maska, oblečenie), umelecký výraz, architektúra (bývanie, usídl’ovanie - telesnost’ v priestore) a pod.

Zatial' čo bytie telom odkazuje tak $\mathrm{k}$ bytiu živého, ako aj materiálneho tela, ktoré sa však zároveň zakladá na subjektívnom tele, je tu aj fenomén tela Körper, ktoré máme, ku ktorému sa teda vzt’ahujeme ako k fyzickému telu. To, že a ako telo máme, sa týka „explicitnej telesnosti““, obrazov tela, predstáv o tele, odstupu od vlastnej telesnosti, situovania tela vo fyzickom svete, čo v určitom zmysle nemusí byt' nevýhodou, ale naopak - „odstup od bezprostredného konania a pocit'ovania, a tým získanie zmyslu pre odstup a kontrolu, umožňuje reflektovat' a hodnotit' svoje telesné správanie. Telo ako objekt teda nemusí byt' nevyhnutne zát'ažou, ale môže byt' aj vyslobodením (v závislosti od okolností)“(Wehrle 2020, 518). Prevaha fyzického tela je niekedy riešením situácie, ktorá je pre človeka neudržatel'ná. „Ako je výsadou človeka dostat' sa do určitej nemožnej situácie..., tak je jeho výsadou aj namiesto seba nechat' odpovedat' fyzické telo“ (Plessner 1970, 155) ako Körperleib. Maarten Coolen použiva jednoduchý príklad, ked' opisuje, ako sa pozerám na obraz a snažím sa nájst’ primeranú vzdialenost', aby som mal'bu videla dobre: pri cúvaní narazím chrbtom na stenu a „nielenže zažívam, že sa mi nepodarí dosiahnut' optimálny výhl'ad, ale z toho tiež cítim, že sa mi nedarí dat' svoje telo na správne miesto, a to mi zase dáva vedomie svojho tela ako veci, ktorá je umiestnená medzi inými vecami“" (Coolen, 2014, 114). Takisto prístup, ktorý berie do úvahy spolu s Leib aj Körper, umožňuje zachytit’ hybridné situácie, $\mathrm{v}$ ktorých sa naša telesnost' prirodzene ocitá, ako je napríklad orientácia v novom priestore, rôzne formy intersubjektívnych situácií pri komunikácii, situácí spôsobených telesnými nedostatkami alebo telesným odcudzením: cvičenie ruky po zranení, intenzívne duševné a telesné zranenia, ako je to napríklad pri znásilnení, alebo aj potreba vyrovnat' sa s odcudzenost'ou pri neosobných administratívnych úkonoch a pod. ${ }^{9}$ Fyzické telo môže poskytnút' stabilizáciu ako určitú záchrannú schému pri reakcii, ktorej nie je schopná spontánna subjektívna telesnost'.

${ }^{9}$ Hybridným skúsenostiam sa venuje J. Copoeru a A. Ludusan v texte Ako prichádzame na veci.
Ako niečo vieme, o hybridných spôsoboch a komunikačných (inter)-akciách (2020). Spracovanie 
Uved'me teraz dva príklady, ked' sa Plessnerov projekt tematizujúci telesnost' stáva aktuálnym. Ide o (1) uplatnenie podvojnosti tela vedúce $\mathrm{k}$ aplikácii v antropologickom výskume, ako aj (2) k možnosti vstúpit' do filozofickej diskusie na pôde súčasnej fenomenológie.

Prienik takto nastaveného skúmania telesnosti by sa dal nájst' na príklade takých projektov, ktoré sa osobitne zaoberajú témou skúsenosti z prvej osoby v antropológii, ako je napríklad Fenomenológia v antropológii. Zmysel pre perspektívu (Ram, Houston 2015), kde sa v rámci kultúrnej antropológie a etnológie sleduje diverzita a nové podoby konfigurácií tela ako kultúrne interpretácie, ktoré vychádzajú z určitej „,práce kultúry“, ako aj lokálna biológia a vnútorné výrazy či idiómy, napríklad pre bolest' alebo pamät'. Pre porozumenie telesným fenoménom treba vnímat' vlastné telo, zmyslovost', byt' účastný na pozorovaní telesnosti druhého, byt' vnímavý na zakúšanie telesnej rovnováhy aj nerovnováhy. Z toho potom vychádzajú spôsoby starostlivosti o vlastnú telesnost'. Fenomenológia zameriava pozornost' aj na nástroje, ktoré sa používajú pri antropologických alebo etnologických analýzach, ako aj na samého výskumníka, ktorý im musí porozumiet' z pozície vlastného prežívania. Antropológovia sú tu oslovení práve takou fenomenológiou, ktorá si uvedomuje hranice poznávajúceho vedomia, a naopak aj dôležitost' skúsenosti (Ram, Houston 2015, 4). ${ }^{10}$

V týchto projektoch sa teda skúmajú podoby a premeny telesnosti z jej subjektívnej a fyzickej stránky ako premeny perspektívy. Môžeme sa však na ňu pozriet' aj z iného aspektu, a to pri filozofickej otázke stávania (werden) ako fenoménu či figúry neustálej podvojnosti telesnosti. Prejdime teda k druhému bodu.

Plessner pri prvom antropologickom princípe prirodzenej umelosti uvádza, že „bytost' v nerovnováhe, stojaca mimo miesta, času, konštitutívne bez domova, sa niekým ,musí stat" a rovnováhu si vytvorit"“ (Plessner 1975, 310). Tretí antropologický princíp utopického stanoviska zase hovorí o mieste človeka ako o jeho „nikde“ (Nicht-Ort), ked’ sa človek nevyčerpáva vo svojom faktickom tu, ale ako osoba má možnost' prekračovat' to, čo dosiahne, brat' svoj život ako úlohu, vidí seba v perspektíve celku sveta i kontingencie a vlastnej nezakorenenosti (Plessner 1975, 341 - 343). K situovaniu telesnej subjektivity tak dochádza na určitom mieste a zároveň na nemieste, čo je vlastným vyjadrením excentrickej pozicionality. Túto perspektívu by sme mohli priblížit' k pojmu oikos, ako ho nachádzame u Hansa Rainera Seppa

témy frustrácie $\mathrm{z}$ administratívneho, byrokratického tlaku pri umeleckej tvorbe nachádzame u slovenského umelca P. Jánošík, ako na to upozorňuje R. Podhorský (2021).

${ }^{10}$ Iným príkladom je zapojenie antropológie do pedagogického výskumu, na ktorý upozorňuje H.R. Müler (2002). Pri „pedagogickej situácii“ sa uplatňuje striedanie perspektív z prvej osoby žiaka a učitel'a, ako aj vlastná telesnost' a odstup od telesnosti pri učení, kde sa dá dobre aplikovat' Plessnerom opísaná podvojnost' telesnosti. Inou možnost'ou je skúmanie patológií, ktoré tematizuje napríklad M. Wehrle (2020) pri hraničných telesných skúsenostiach a konštitúcii časovosti. 
(2014). ${ }^{11}$ Sepp rozvíja pojmy zeme, miesta a étosu a rozlišuje telo ako hranicu (GrenzLeib), smerujúce telo (Richtung-Leib) a telo ako zmysel (Sinn-Leib). Zachytáva vzt’ahy subjektivity a okolia, sveta ako určitú „stabilnú nerovnováhu“. ${ }^{12}$ Človek participuje na vzt'ahoch $\mathrm{k}$ miestam, ktoré sa určujú z jeho telesnosti a vyjadrujú fakticitu väzby k „tu“. No zároveň sa ustavične nachádza aj vo vzt'ahu k ne-miestu, k „nič“, respektíve akoby nebol „nikde“. K pojmu stabilnej nerovnováhy by sme tak mohli pripojit' aj Plessnerov projekt, ktorý sa zakladá na napätí medzi pozicionalitou a excentricitou, podobne ako to Sepp vidí u Husserla, Heideggera, Finka, Levinasa a Patočku: ,„.. fenomenológia - na pozadí línie, ktorá vedie $\mathrm{v}$ dejinách európskej filozofie od Mikuláša Kuzánskeho cez Leibniza po Nietzscheho - predložila sériu kl'účových operácí́, ktoré nevedú $\mathrm{k}$ ničomu inému než práve $\mathrm{k}$ stabilnej nerovnováhe, ako to ukazuje napríklad diferencia prirodzeného a transcendentálneho postoja u Husserla, neautentického a autentického modu bytia u Heideggera, vnútrosvetského a sveta u Finka, konečnej a nekonečnej túžby u Levinasa alebo idolu a ikony u Mariona. V žiadnom z týchto prípadov nejde o nahradenie jedného modu druhým, ale o ich vzt'ah napätia, pričom napätie, stabilná nerovnováha sa vždy ukazuje a udržuje cez druhý modus. Aj u raného Patočku sa razantne zdôrazňuje, že ,život v amplitúde“ sa má uprednostnit' pred ,životom v rovnováhe““ (Sepp 2014, 9). Ako takéto východisko sa javí aj Plessnerom opísaná podvojnost' telesnosti, rôzne podoby Leibkörperlichkeit, ktorými sa telo deje, vyrovnáva sa so sebou a svetom. „Excentrická pozicionalita znamená odstup od tela v tele, alebo inými slovami, odstup od života vnútri života“ (Fischer 2014, 51). To, že telom sme aj ho máme, spôsobuje ich neustále vyrovnávanie, a tým ustavovanie seba v živote.

\section{Telo a pojem l'udskosti - nové možnosti biológie}

Inou otázkou je pohl'ad na Plessnera v súvislosti s biologickým alebo zoologickým diskurzom, respektíve otázka, či možno rozvinút' produktívny dialóg aj so súčasným vedeckým výskumom. V nasledujúcej časti poukážeme na cestu, ktorá by mohla priniest' pozitívnu odpoved' a zároveň naznačit', prečo je dôležité si v kontexte Plessnerovho diela túto otázku klást'. Bez toho, aby sme sa stratili v špecializovaných výskumoch, siahneme po vybranom meta-uvažovaní v biológii, respektíve filozofii biológie zameriavajúcej sa na pojmy l'udského a mimo-l'udského, živého a umelého, nel'udského a nie-l'udského, a to opät' v súvislosti s témou telesnosti, ktorá predstavuje základný príklad excentrickej pozicionality. Antropologická diferencia je odkázaná na ich reaktualizáciu aj rekonfiguráciu. Práve na tento bod chceme nadviazat' uvažovaním francúzskeho biofyzika Henriho Atlana.

${ }^{11}$ Ako aj v analýze tejto koncepcie u Karla Novotného (2016) vo vzt’ahu k telesnosti a afektivite.

${ }^{12} \mathrm{~S}$ odkazom na zoológa, evolučného biológa a ekológa J. H. Reichholfa. 
Styčný bod medzi Atlanovým prístupom a Plessnerovým projektom filozofickej antropológie nachádzame $\mathrm{v}$ tom, že obaja sa vymedzujú voči koncepcii čistého ega alebo čistého vedomia, na rozdiel napríklad od skorších Husserlových textov, ${ }^{13}$ no mohli by sa spolu stretnút' aj v tom, ako Atlan uvažuje o pojme l'udského, respektíve o pojmoch súvisiacich s l'udským bytím. Tie majú charakter otvorenosti, reaktualizácie či operatívnosti na rozdiel od esenciálnych určení, čo podobne ako u Plessnera neumožňuje fixovat' jeden základ či jadro l'udskosti. To sa rozvrhuje a konfiguruje v excentrickej pozicionalite. Druhou spájajúcou črtou je platforma filozofie biológie či bio-filozofie, ktorú zastáva aj Plessner. ${ }^{14} \mathrm{~K}$ filozofickej antropológii totiž patrí „,primeraná filozofia biológie, ktorá je kompatibilná s teóriou života vo všeobecnosti, ale takisto je primeraná interpretácii človeka“ (Fischer 2014, 48). Tak ako spolupráca biológie a antropológie vyústila na začiatku dvadsiateho storočia do inšpiratívnych projektov, ktoré napríklad umožnili prekonat' filozofický pohl'ad na dualizmus tela a duše (Plessner 2017, 354 - 356), aj dnes nachádzame potenciál čerpat’ z filozofie biológie podnety pre otázku človeka. Na túto optiku sa zameriava Henri Atlan, ktorý však upozorňuje, že dvadsiate storočie „bolo svedkom nevídane rýchleho napredovania vedomostí a technických výkonov, a to najmä - aj ked' nielen - v oblasti vied o živote. Toto rýchle napredovanie nezmenilo iba hmotné podmienky našej existencie, ale aj a hlavne - naše predstavy o svete, o nás samých i o veciach, čo nás obklopujú. Staré klasifikácie prestali byt' relevantné. Odlíšenia, ktoré sme považovali za pevne stanovené, a hranice, ktoré sme považovali za neprekročitel’né, sú zrušené či prinajmenšom posunuté nevedno kam. Zvlášs' pojem l'udskosti (humanité), ktorý odlišoval l'udské od nie-l'udského, sa zdá problematickejší než kedykol'vek predtým“ (Atlan 2008, 104). Otázky súvisiace s podmienkami a možnost’ami realizácie človeka aj Plessner pokladá za dôležité položit' nanovo.

Atlan sa najskôr kriticky sústred’uje na dichotómiu živého mysliaceho a hmotného neživého, ktorá zvykla delimitovat' oblast' l'udského a zároveň zaviedla dualizmus, ktorý sa premietal aj do oblasti tela. No nový prístup k telesnosti ukazuje, že „na

\footnotetext{
${ }^{13}$ Atlanov prístup je v určitej kolízii s fenomenológiou a jej koncepciou čistého ega, ako aj kritikou prírodovedného prístupu, ktorý je vyzátvorkovaný fenomenologickou metódou. Atlan navrhuje „symetricky“ $\mathrm{k}$ transcendentálnej redukcii práve takú redukciu, ktorá bude brat' do úvahy prírodovedný, biologický základ pre vysvetlenie vedomia (Atlan 2011,71). Ďalej napríklad pracuje na modeloch, ktoré zobrazujú „možné fyzické vynorenia našej intencionality“. Porov. Atlan (2008, 110; 2011, 65 a n.).

${ }^{14}$ Aj Plessnerova pozícia je založená v oblasti filozofie biológie, nie biologizmu (porov. Klein 2011, 77 a n., Fischer 2014, 47 a n.). Môžeme tu spomenút' alternatívne aj d'alšie stratégie vzájomného prelínania vedeckého a filozofického diskurzu, ktoré sú známe aj v našom prostredí napríklad v prácach J. Šebestíka, L. Kováča, I. M. Havla, Z. Neubauera, P. Sýkoru, A. Markoša, S. Komárka. Takisto možno spomenút' aktuálny výskum filozofickej antropológie, ktorý rozvíjajú výskumné skupiny na FHS UK v Prahe a FF Univerzity v Hradci Králové, tu najmä v súvislosti s A. Portmannom (porov. nedávno vydaný článok I. R. Vajdovej, 2021).
} 
pochopenie aktivity živého tela netreba vzývat' nehmotnú dušu“ (Atlan 2008, 105). A hoci procesy samousporiadania hmoty a emergencie živého sú $v$ oblasti vedy opísane mechanisticky, nemusíme z nich hned' fixovat' pojem l'udského. Inými slovami, s mechanistickým či fyzikalistickým opisom vedomia nevyhnutne nemusíme stratit' pojem l'udskej bytosti či slobodného konania. V každodennom živote a v spoločnosti sa rozhodujeme, cítime, konáme ako l’udské bytosti, aj ako bytosti obdarené tým, čo pokladáme za vedomie, vôl'u, slobodu, schopnost' pamätat' si, reflektovat'. Takisto biotechnologický pokrok podl'a neho nevyhnutne neznamená potlačenie človeka a príchod obdobia posthumanity, ale skôr modifikovanie určitého obrazu človeka, ktorý sa filozoficky fixoval $\mathrm{v}$ tradícii podstaty vedomia, stvorenia alebo určitej predstavy prírody. Aj Plessner vidí úlohu antropológie skôr v premyslení aktuálnej situácie človeka a v obozretnom (skeptickom) vnímaní tradovaných predstáv toho, kým človek je alebo by mal byt', v preverovaní pesimistických vízií vymiznutia a ohrozenia človeka či inak vyhranených faktorov l'udskej prirodzenosti (Plessner 2017, 363, 365). Namiesto výkladových schém sa antropológia zameriava na konkrétnu skúsenost' človeka, a tak na podoby jeho správania.

Určenie človeka sa zároveň nedotýka len rozhrania živého a neživého, ale aj vedomého a nevedomého, pre ktoré Atlan nehl'adá esenciálne definície (určenia stupňa vedomia alebo genetického základu), ale navrhuje evolutívne definície zamerané na emergenciu života, vedomia a tela, na to, že sa niečo „stáva“ živým, vedomým alebo telesným. Ak si prepožičiame upozornenie J. Brudzińskej, nachádzame tu kl'účový bod v pojme „živého, ktorý sa raz javí ako príroda, raz funguje ako súvislost' a horizont výkonov zmyslu l'udských subjektov“ $(2018,22)$.

V pozadí l'udského konania, správania a vôle existuje mnoho determinantov a mechanizmov, ktoré v tradičnom pohl’ade narážajú na predstavu človeka ako slobodnej bytosti. Zdá sa, že niektoré otázky - „kde je hranica medzi bielou krvinkou, ktorá prestupuje steny ciev a smeruje k svojej koristi, a psom, ktorého správanie je možno úmyselné? Nachádza sa na úrovni nálevníka, ryby alebo žaby? A ako je to s nami?"“(Atlan 2008, 110) - skôr prehlbujú dichotómie, než prinášajú účinné vysvetlenia. Atlan preto uprednostňuje takú odpoved' na otázku pojmu l'udského, ktorá je ukotvená v kultúrnej evolúcii, v komplexe živého, ktorý sa prepája so spoločenským, jazykovým, historickým, morálnym, právnym aj imaginatívnym. Z toho potom vychádza aj uvažovanie o nie-l'udskom ako o opaku toho, čo patrí k l’udskému rodu, a ne-l'udskom ako o opaku l'udského ako humanity, ktoré sa nedá redukovat' na biologickú rovinu. Ukazuje sa tu teda premena l’udského vo vzt'ahu k tomu, čo predstavujú koncepty nie-l'udského a ne-l'udského. V nadväznosti na Spinozu potom Atlan prepája pojem l'udského s dôstojnost'ou, ktorá predstavuje akési minimum uznania l’udskosti, a zároveň je to telo, ktoré má svoju nezamenitel'nú fyziológiu, je to tvár 
človeka, človek so svojím vzt'ahom k oblečeniu a nahote, telo, ktoré je spojené aj s intersubjektívnou, spoločenskou realitou..$^{15}$ Telo tu vystupuje v prepletení s vedomím do tej miery, že vytvára monizmus, ktorého základom je pamät'. Konštitúcia vychádza z vlastnej organizácie živého systému, nie z vonkajších zdrojov, ktoré by mu ako „iskra“" (výboj či Sila) poskytovali dôvod existencie.

Tu môžeme opät' poukázat' na súvislost' s Plessnerom, u ktorého sa excentricita odohráva vždy spolu s pozicionalitou. Pričom pozicionalita sa stáva podla J. Fischera kl'účovým aj perspektívnym pojmom v kontexte filozofie biológie (podl'a neho azda výstižnejším než autopoiésis), pretože „obsahuje ponímanie stávania sa života organizmu, ked' je kladený alebo poziciovaný vo svojich hraniciach“ (Fischer 2014, 51). Tento otvorený či evolutívny koncept excentrickej pozicionality „,by mohol byt' primeranou cestou, ako v rámci príslušnej filozofie biológie uchopit' sociokultúrnu dimenziu človeka" (Fischer 2014, 53).

\section{Záver: Sonderstellung ako nerovnovážna rovnováha}

Filozofická antropológia zachytáva človeka v jeho „nedohotovenosti“, podvojnosti jeho existencie, ktorá osciluje medzi vrhnutost’ou do postoja a konštituovaním svojho stanoviska, uvedomovaním si a pocit’ovaním vlastnej pozicionality. Filozoficky sa to dá vyjadrit' aj ako ustavičná prítomnost' rozporu, nedostatku, nestability, absencie, ničoty (ako to vyjadruje v kontexte M. Schelera a H. Plessnera H. R. Sepp 2014, 56, 57), ktorá je konštitutívna pre to, ako človek ustanovuje svoje miesto vo svete. Odstup od seba v sebe umožňuje aj jeho prekonávanie. Bio-filozoficky to zase vyjadruje stávanie živého organizmu, ktorý sa vyjadruje v nejakom druhu l'udského výrazu ako telesného. Filozofická antropológia $\mathrm{v}$ tomto zmysle môže ostat' $\mathrm{v}$ určitom dialógu $\mathrm{s}$ vedou bez toho, aby sa jej závery stratili v nových vedeckých paradigmách, ked’ reaguje na filozofické aspekty vedeckého výskumu.

Helmuth Plessner sa pokúša komplexne zachytit' dynamickú konfiguráciu, ktorá ustanovuje to, čo predstavuje hl'adisko človeka. Je aj subtílnym ${ }^{16}$ pozorovatel'om situácie človeka, spoločnosti, politiky, vedy, techniky i umenia, čo dokladá rozsiahla tematika jeho textov. A navyše ako kritický diagnostik neupadá do skepsy a pesimizmu v súvislosti s pojmom l’udského. Viacerí interpretátori (Mul et al. 2014, Fischer 2014) zdôrazňujú, že napriek turbulentným zmenám situácie človeka, jeho pozicionality, ako aj rámcov vedeckého a biologického výskumu v porovnaní s obdobím, v ktorom pôsobil a ktoré reflektoval Plessner, je jeho konceptualizácia excentrickej pozicionality

15 „Telo príslušníka druhu homo sapiens a jeho tvár sú okamžite vnímané ako l'udské. Sú identifikovatel'né aj bez vedeckého skúmania a bez analýzy DNA, l’udské telo nie je zamenitel'né s telom nijakého iného druhu, ani s telom robota, nech by bol aj inteligentný“ (Atlan 2008, 115).

${ }^{16}$ Toto označenie sa opakovane objavuje napríklad u Fischera (2014). 
výstižná aj dnes. Je výstižná práve v tom, ako sa usiluje pozerat' na človeka jeho vlastnými očami - ako telesného, zaujímajúceho roly, vyjadrujúceho sa v expresiách, ako na človeka, ktorý sa nachádza v určitej dejinnej situácii, či už v prvej polovici dvadsiateho storočia, alebo aj v celkom inej situácii človeka nového milénia.

\section{Literatúra}

ALTAN, H. (2008): Žit’ a poznat': sociálne reprezentácie a biologické artefakty. In: Karul, R. - Muránsky, M. - Vydrová, J. (eds.): Vnimat', konat', mysliet'. Bratislava: Filozofický ústav, 104 - 117.

ATLAN, H. (2011): Selected writings. On Self-Organization, Philosophy, Bioethics, and Judaism. New York: Fordham University Press.

BRUDZIŃSKA, J. (2018): Phänomenologie als Anthropologie der Erfahrung und moderne Philosophie des Menschen. Philosophische Anthropologie. Themen und Positionen. Band 8: Philosophische Anthropologie zwischen Soziologie und Geschichtsphilosophie. Verlag Traugott Bautz, $15-33$.

COPOERU, I., LUDUŞAN, A. (2020): We Will Figure It Out. Know-how, Hybrid Ways, and Communicative (Inter)actions. Studia UBB Philosophia, 65 (3), 33 - 50.

COOLEN, M. (2014): Bodily Experience and Experiencing One's Body. In: Mul, J. de (ed.): Plessner's Philosophical Anthropology. Perspectives and Prospects. Amsterdam: Amsterdam University Press, $111-127$.

FISCHER, J. (2014): Philosophical Anthropology. A Third Way between Darwinism and Foucaultism. In: Mul, J. de (ed.): Plessner's Philosophical Anthropology. Perspectives and Prospects. Amsterdam: Amsterdam University Press, $41-56$.

HALÁK, J., KLOUDA, J. (2018): The Institution of Life in Gehlen and Merleau-Ponty. Searching for the Common Ground for the Anthropological Difference. Human Studies, 41(3), $371-$ 394. DOI: https://doi.org/10.1007/s10746-018-9469-5

KLEIN, R. (2011): Sociality as the Human Contition. Anthropology in Economic, Philosophical and Theological Perspective. Leiden, Boston: Brill. DOI: https://doi.org/10.1163/ej.9789004191990.i-324.2

MUL, J. de (ed.) (2014): Plessner's Philosophical Anthropology. Perspectives and Prospects. Amsterdam: Amsterdam University Press.

MÜLER, H.-R. (2002): Exzentrische Positionalität. Bildungstheoretische Überlegungen zu einem Theorem Helmuth Plessners. In: Wigger, L. (ed.): Zeitschrift für Erziehungswissenschaft. Forschungsfelder der Allgemeinen Erziehungswissenschaft. Beiheft 1. Opladen: Leske und Budrich, $53-61$.

NOVOTNÝ, K. (2016): Relevance subjektivity. Tělo a duše z hlediska fenomenologie afektivity. Červený Kostelec: Pavel Mervart.

PLESSNER, H. (1970): Philosophische Anthropologie. Lachen und Weinen, Das Lächeln, Anthropologie der Sinne. Bern: S. Fischer Verlag.

PLESSNER, H. (1975): Die Stufen des Organischen und der Mensch. 3. Auflage. Berlin - New York: De Gruyter.

PLESSNER, H. (2017): Homo absconditus. In: Condition humana. Gesammelte Schriften VIII. 3. Auflage. Frankfurt am Main: Suhrkamp Verlag, 353 - 366.

PLESSNER, H. (2016): Die Deutung des mimischen Ausdrucks. Ein Beitrag zur Lehre vom Bewußtsein des anderen Ichs. In: Ausdruck und menschliche Natur. Gesammelte Schrigten VII. 2. Auflage. Frankfurt am Main: Suhrkamp Verlag, 67 - 129.

PLESSNER, H. (2017a): Über das Welt-Umweltverhältnis des Menschen. In: Condition humana. Gesammelte Schriften VIII. 3. Auflage. Frankfurt am Main: Suhrkamp Verlag, 77 - 87.

PLESSNER, H. (2017b): Die Frage nach der Conditio Humana. In: Condition humana. Gesammelte Schriften VIII. 3. Auflage. Frankfurt am Main: Suhrkamp Verlag, 136 - 217. 
PLESSNER, H. (2019): Philosophische Anthropologie. Göttinger Vorlesung vom Sommersemester 1961. Berlin: Suhrkamp Verlag.

PODHORSKÝ, R. (2021): Osobné a neosobné v tvorbe Petra Jánošíka. Ostium, 17 (1), 1 - 10.

SEPP, H. R. (2014): Grundrisse einer oikologischen Philosophie. Středoevropský institut pro filosofii (SIF)/ Mitteleuropäisches Institut für Philosophie. Dostupné na: https://www.sif-praha.cz/wpcontent/uploads/2014/07/HRS-oikologische-Philosophie.pdf (Navštívené: 3. 8. 2021).

VAJDOVÁ, I. R. (2021): Filozof vedy o živom. Filozofia, 76 (5), 351 - 363. DOI: https://doi.org/ 10.31577/filozofia.2021.76.5.3

VYDROVÁ, J. (2021): The Intertwining of Phenomenology and Philosophical Anthropology: From Husserl to Plessner. In: Šajda, P. (ed.): Modern and Postmodern Crises of Symbolic Structures. Leiden, Boston: Brill, 41 - 62. DOI: https://doi.org/10.1163/9789004440968_005

VYDROVÁ, J. (2016): Prítomnost’ človeka. Antropologický prístup Helmutha Plessnera. Filozofia, $71(7), 562-571$.

WEHRLE, M. (2013): Medium und Grenze: Der Leib als Kategorie der Intersubjektivität. Phänomenologie und Anthropologie im Dialog. In: Breyer, Th. (ed.): Grenzen der Empathie. Philosophische, psychologische und anthropologische Perspektiven. Paderborn: Wilhelm Fink Verlag, $217-238$.

WEHRLE, M. (2020): Being a body and having a body. The twofold temporality of embodied intentionality. Phenomenology and the Cognitive Sciences, 19, 499 - 521. DOI: https://doi.org/ 10.1007/s11097-019-09610-z

ZAHAVI, D. (2019): Applied phenomenology: Why it is safe to ignore the epoché. Continental Philosophy Review (2), 1 - 15. DOI: https://doi.org/10.1007/s11007-019-09463-y

Tento text vznikol na Katedre filozofie Filozofickej fakulty Trnavskej univerzity v Trnave ako súčast' riešenia grantovej úlohy VEGA č. 1/0174/21.

\author{
Jaroslava Vydrová \\ Trnavská univerzita $\mathrm{v}$ Trnave \\ Filozofická fakulta \\ Katedra filozofie \\ Hornopotočná 23 \\ 91843 Trnava \\ Slovenská republika \\ e-mail: jaroslavavydrova@gmail.com \\ ORCID ID: https://orcid.org/0000-0001-6046-0074
}

